\title{
THE ROMANIAN PREZIDENTIALIZED CONSULTATIVE REFERENDUM. EATING APPLES FROM A POISONOUS TREE? PERSONAL AND TELEOLOGICAL INTERPRETATIONS
}

\author{
Răzvan Cosmin Roghină \\ „Lucian Blaga” University of Sibiu, Romania, E-mail: razvan.roghina@ulbsibiu.ro
}

(Received: September 2019; Accepted: October 2019; Published: November 2019)

\begin{abstract}
Through this article, we propose an (original) analytical approach on the consultative referendum of May 2019 and a wider critical landscape regarding the consultative referendum institution by enforcing a teleological interpretation. In this sense, we propose three sections. We will start with a short overview on the use of the consultative referendum in the recent years of Romanian democracy. In the second section we will focus on the consultative referendum from 26 May, 2019. In the third section we will ask the Founding Fathers of the Constitution for an "opinion" regarding the possibilities and impossibilities of the consultative referendum.
\end{abstract}

Keywords: Consultative Referendum, Romanian Constitution, head of state authoritarianism, constitutional coherence.

\section{Introductive considerations}

The Constitution of Romania, in article 90, gives the president the possibility to ask the People, after consulting the Parliament, to express their will regarding issues of national interest. The popular will comes to be known by organizing a referendum (consultative). This political and democratic instrument of the president is not limited by a counter-guarantee on behalf of other public authorities. However, the apparent autonomy of the president regarding the use of the consultative referendum can be reversed by exploring the Constitution through its entire power distribution mechanism.

Article 90 establishes a consultative referendum. But once initiated, its finalization illustrates the will of the People with respect to a certain issue of national interest. Therefore, the question arises whether the popular answer can be ignored by the supreme representative body in a situation when the objectification of the will of

\footnotetext{
* Corresponding author: Răzvan Cosmin Roghină.E-mail: E-mail: razvan.roghina@ulbsibiu.ro
} 
The Romanian prezidentialized consultative referendum. Eating apples from poisonous tree? Personal and teological interpretations

the People would stand in its parliamentary power? The result of a consultative referendum is not obligatory to follow but certainly bears moral pressure. Who can channel this moral pressure? Given that the initiator of the referendum can only be the president, it is expected, in scenarios where the parliament is in a disagreement with the president, that head of state will be the one to invocate and try to use the popular expression in a subjective political sense, of course if the result of the referendum came out to be the one he pursued. The Constituent from 1991 certainly did not aim to grant these subjective possibilities to the president.

That is why, through this article, we propose - somehow continuing the ideas presented in the articles "The survival of the Romanian Head of State Authoritarianism in Romanian Democracy through the Consultative Referendum" [1] and "The Constitutional Court of Romania against the Direction of the Constitutional Moment of 1991" [2] - an analytical approach on the consultative referendum of May 2019 and to project a wider critical landscape regarding the consultative referendum institution by enforcing a teleological interpretation. In this sense, we propose three sections. We will start with a short overview on the use of the consultative referendum in the recent years of Romanian democracy. In the second section we will focus on the consultative referendum from May, 2019. In the third section we will ask the Founding Fathers of the Constitution for an "opinion" regarding the possibilities and impossibilities of the consultative referendum.

\section{The use of the consultative referendum in the recent years of the Romanian democracy [3]}

The year 2007 reveals two referendums. The first one was organized for the dismissal of the president, which was obligatory and decisional (constitutionally binding), once the suspension procedure was finalized by the Parliament. The result of the referendum was invalidated because the electoral threshold was not met.

After the referendum for his dismissal was invalidated, the president Traian Băsescu decided, more in the form of a reply given to the Parliament, to ask the Romanian people if they agree with the introduction of the majority uninominal vote with two rounds for the election of the members of the Parliament of Romania, in the context in which until then the parliamentarians were elected based on list ballot. Therefore, a 2nd referendum was organized based rather on the presidential desire to pay some political policies.

The president, concentrated on an electoral strategy aimed to increase his personal electoral capital, without neglecting that of the political party of origin, scheduled the consultative referendum on November $25^{\text {th }}$, in the same day with the European

24 sciendo Journal of Legal Studies Volume 24 Issue 38/2019 ISSN 2457-9017; Online ISSN 2392-7054.

Web: publicatii.uvvg.ro/index.php/jls. Pages $23-43$ 
The Romanian prezidentialized consultative referendum. Eating apples from poisonous tree? Personal and teological interpretations

Parliament elections (it was the first time when Romania participated). By doing so, the president was able to get involved in the European elections campaign through the information campaign implied on the subject of the consultative referendum. As a result, the political equidistance imposed by the Constitution and constitutional policy was abandoned by the head of state. With a presence of only $26.51 \%$, the electoral threshold was not reached. In consequence, the referendum was invalidated, but, in truth, further validated some external-constitutional power leverages for the president in the People mentality.

In 2009, less than two months after the adoption of the Emergency Ordinance no. 103 of 30th September 2009, by which was added a term of 20 days at most for the response of the Parliament to the President's request for organizing a consultative referendum, the President of Romania sent a request of consultation to the presidents of the Chambers, regarding a consultative referendum having as a subject the reduction of the parliamentarians' number to 300 and the necessity, in his opinion, to switch to an unicameral parliament. Relying on Decision 567/2007 of the CCR, the President proposed, indirectly, a constitutional revision, concretely of art. 61 of the Constitution, regarding the structure of the Parliament.

Despite the Parliament's negative vote, the President considered that he had respected his only obligation in the referendum procedure, namely to consult the Parliament, and defiantly, on the very next day, issued the decree on the organization of the referendum, which he scheduled on the same day with the presidential elections, for obvious electoral reasons.

Thus, the information campaign on the topic of the referendum overlapped with the one for the electoral campaign for the election of the President of the state, a situation which confused the electorate, or, better said, consciously placed it in the illusion of solving a conflict between a good President, a representative of the People, and a corrupt Parliament, a representative of its own interests.

We will not analyze the content of the informative campaign regarding the referendum. It is a well-known fact that, in reality, it was nothing other than an aggressive discrediting campaign aimed against the legitimacy of the Parliament, which even involved slogans with a direct message in this regard, such as "They won't escape that which they fear!". Such messages were projected on "informative" posters with the referendum initiator, and the colors were similar to those used by the president in the election campaign for his re-election. Such an expression from the President, in the exercise of art. 90 of the Constitution, cannot be discussed through democratic principles, through the principles and coordinates of the Romanian Constitution.

At the end of 2009, the referendum and the deliberative democracy, two instruments which seemed inseparable, were two parallel realities. This was due to 
The Romanian prezidentialized consultative referendum. Eating apples from poisonous tree? Personal and teological interpretations

the way in which the referendum was utilized by a President who prioritized his own political interests through the illusion of absolutizing the People's political power.

The democratic finality of the referendum was clearly frustrated by the political conduct of the President, coupled with a flagrant infringement of his political role and of the constitutional limits which he should have complied to. As such, we reiterate the need for a genuine control over the constitutionality of the presidential decrees on the initiation of the consultative referendum procedure. At the moment, an organ of the state, which will declare itself competent, is awaited, in compliance with the rule of law. The Constitutional Court is limiting itself in the scheme of article 90 of the Constitution, interpreted in a rigid, isolated way.

Participatory democracy was turned, through the "mediation" (or, better said, "the urge") of the President against representative democracy. Once the "victory" in the 2009 referendum was obtained, the President increased his power in relation with the Parliament, benefiting from the People's mandate to fight against the large number of corrupted members of the Parliament, in his new term. Thus, the referendum affected the legitimacy of the Parliament and strengthened that of the President, contrary to the representative government coordinates set by the Constitution. When the ulterior context required it, the President did not hesitate, in the absence of a favorable parliamentary majority (consolidated governmental majority), to remind the Parliament the results of the referendum, perpetuating, as such, the discrediting of the legislative body.

Recently, with the occasion of the popular manifestations caused by Emergency Ordinance 13/2017, President K. Iohannis declared his intention of asking the People to express its opinion by giving an answer to a general question which could not bear, practically, any other answer other than yes for continuing the fight against corruption and for ensuring the integrity of public functions.

Just like in 2009, such a referendum would have had a plebiscitary character, bearing in mind the objectm which would have been the subject of public debate. It would not have been anything other than another fait accompli type of policy coming from a President ready to reap the electoral rewards that had grown in a certain political context. As a result, the scheme of the personalization of the political power could have developed even further in the political psychology of the Romanian voter. It is undoubtable that the way article 90 of the Constitution is interpreted and applied is encouraging power personalization in the President's account. Therefore, the tradition of an authoritarian head of the state survives.

In 2019, another consultative referendum was held, having as primary source of reasons: a) the popular movements of 2017, endorsed by the adoption of the Emergency Ordinance (EO) 13/2017 (for the modification and completion of the

26 Sciendo Journal of Legal Studies Volume 24 Issue 38/2019 ISSN 2457-9017; Online ISSN 2392-7054.

Web: publicatii.uvvg.ro/index.php/jls. Pages $23-43$ 
The Romanian prezidentialized consultative referendum. Eating apples from poisonous tree? Personal and teological interpretations

Criminal Code and Criminal Procedure Code) and b) other amendments and projects meant to revise some provisions of criminal law (called "assault on justice" in the popular public language), from 2018 and 2019. The referendum on justice, as it was called in the societal / public dialogue area, was yet another presidential work, endowed, beyond some correct and objective coherence and motives, impulses of personal and political party electoral strategy. As proof, President K. Iohannis set the referendum date on the same day with - again European Parliament Election Day, as president Traian Băsescu did, in 2007, on the political chessboard.

So, the consultative referendum was held on the same day with the Europarliamentary elections, on May $26^{\text {th }}, 2019$, which again ensured the possibility for presidential involvement in the election campaign of the political party of origin, promoting the need to send a vote of blame to the party holding the parliamentary majority in the national forum of legislature. In the psychology of the electorate, the euro-parliamentary elections merged, consequently, with a sanction vote (vote of no confidence) for the national parliamentary majority.

All these episodes were possible with the help of the Romanian Constitutional Court (CCR), as "hard" as it sounds [4]. The constitutional justice transformed Article 90 into a discretionary competence/ right of the head of state, contrary, as we shall see, to the will of the Founding Fathers from 1991.

By Law no. 3/2000 (regarding the organization and conduct of the referendum), respectively through the repeated changes that were made to it, the legislator proposed to define "problems of national interest", by expressly and limiting the issues that may be submitted to the consultative referendum, respectively time limits. The purpose assumed was an obvious one, namely to temper the possible power outages of the president (outside the principle of constitutional loyalty and outside his constitutional role [5] and attributions). The Constitutional Court, in the light of the interpretations included in several decisions [6], determined, as an effect, the transformation of article 90 of the fundamental law into an absolute right of the president, a power leverage that can be used discretionarily by the head of state, if though the Court notified that there is a risk of improper use of the referendum by the president.

Regarding the use of the consultative referendum, the Court's arguments focused, most of the time, on the risk of parliamentary abuse, ignoring the similar risk, perhaps even more clearly, that could come (and came, in several occasions) from a president who may not, considering Constitution dictate, interfere in the activity of other public authorities, discrediting them and disrupting their proper functioning. Illustrative in this sense is Decision no. 334/2013 [7] - on the notification of unconstitutionality regarding the changes brought to the referendum 
Roghină, R.C., (2019)

The Romanian prezidentialized consultative referendum. Eating apples from poisonous tree? Personal and teological interpretations

law following the reduction of the quorum of participation to $30 \%$. The principle of constitutional loyalty is brought to light by the CCR, a principle that could have been used also in the Decisions that failed to limit the volitional autonomy of the president in the exercise of article 90 of the Constitution, thus failing in reactivating the will of the constitutional Founding Fathers from 1991.

The Court notes that changing the participation quorum at a referendum is a matter for the legislator, but the constitutional court must ensure that the instrument is not used for purposes other than those which the Constituent legislator had contemplated, namely as a legal institution essential in a state governed by the rule of law - a form of direct participation of the citizens in the decision-making. The Court must ensure compliance to the principles of legal stability in the referendum legislation area, as well as to the principle concerning the loyal consultations of the citizens, principles, which presuppose the creation of all necessary conditions for the voters to know the issues settled by the referendum (...)

The Court notes that the parliamentary majority initiated the revision of the Constitution. Even though it is undeniable that the Parliament is the supreme legislative body, this legislative behavior must be subject to the principle of constitutional loyalty, which presupposes the collaboration of all the state powers, without the use of disproportionate or abusive means to achieve political ends. The preservation of the rule of law and democracy obliges the Constitutional Court, as supreme guard of the Constitution, to prevent the consequences of unexpected changes of the legal provisions in the field of referendum and to comply with the established legal stability principles (which require clarity, predictability and accessibility), the principles of loyal consultation of the citizens with the right to vote, of the freedom of choice and of the interpretation, with good faith, of the letter and the spirit of the Constitution, principles which constitute structural elements / valences of the general principle of legal security, unanimously accepted within the constitutional democracy. (...) [8].

3. Personal interpretation on the consultative referendum, in the context of its use from May $26^{\text {th }}, 2019$

A consultative referendum, comprising two questions, on the subject of justice - as it was expressed by its initiator, president K. Iohannis, was held on $26^{\text {th }}$ of May, 2019, simultaneously with the elections for the European Parliament, as we already highlighted.

Question 1: Do you agree with the prohibition of amnesty and pardoning for

28 sciendo Journal of Legal Studies Volume 24 Issue 38/2019 ISSN 2457-9017; Online ISSN 2392-7054.

Web: publicatii.uvvg.ro/index.php/jls. Pages $23-43$ 
The Romanian prezidentialized consultative referendum. Eating apples from poisonous tree? Personal and teological interpretations

corruption offenses? (our translation from Romanian [9])

The Constitutional Court, by Decision no. 70/1999 [10], established that the constitutional right of the President of Romania to resort to a consultative referendum cannot confer him the possibility of legislate, since, according to the will of the Romanian Constituent, the president cannot initiate a legislative referendum, but only an advisory one.

Then, what happens when the objectification of the will of the people (derived from the result of the consultative referendum) can only be carried out through legislation? It should be noted that the president has no right of legislative initiative. The head of state cannot objectify a result that implies legal regulation, because he does not have the necessary constitutional and (constitutionally fair) political leverages. Thus, we may ask: can the President program or provoke, through a referendum, moral / political obligations and pressures on behalf of the Parliament, by virtue of its constitutional role provided by article 80? If the answer is "yes", can we maintain the hypothetical positive answer in the conditions of a negative parliamentary notification on the presidential initiative? It the answer is still "yes", we wonder, rhetorically: does the principle of constitutional loyalty have no relevance / importance? Is constitutional policy secondary to political policy, secondary to personal electoral agendas?

$\mathrm{Be}$ it consultative, a referendum is organized with the intention of producing effects. In this context, the singular interpretation of article 90 of the Constitution, isolated from the other constitutional norms, may be a proof of a weak constitutional experience (although, after the constitutional moment of 1991, some years have passed with various political experiences). We have to consider, for example, article 74 para. 4 of the Constitution, which limits the citizens' legislative initiative, in the sense that they are not allowed to manifest any will to legislate on tax matters, on international issues and, nota bene, on amnesty and pardoning. It is not about mixing, confusing two different legal situations, but about achieving a constitutional coherence regarding limits of capacities, about understanding possibilities and meanings, in the initiative right of the citizens, on the one hand, and about political assumptions constitutional logic, in the president's right, on the other hand.

The referendum of May $26^{\text {th }}$ aimed to express the will of the people regarding amnesty and pardoning, although the same people cannot put in a parliamentary debate a legislative proposal in the matter of pardoning and amnesties. We observe a constitutional incoherence, which we will further debate in the section dedicated to the teleological interpretation of the consultative referendum, in order to substantiate the relevance of the corroboration of art. 90 with art. 74 paragraph 4 (apparently, the two articles would have different regulatory objects, with contrast 
The Romanian prezidentialized consultative referendum. Eating apples from poisonous tree? Personal and teological interpretations

ratios [11]). The constitutional incoherence registered also reveals an incoherence regarding criminal policy, caused by emotions, hatred towards certain individuals and certain political parties.

That state of emotional lability was, unfortunately, highlighted in a complex legal sphere, that of criminal law, and was cultivated by the president, enlisting solutions within the policy of criminal law, even though he does not have the specific and necessary attributions and leverages for establishing and assuming a qualified and (presumed) coherent criminal law policy. If the fundamental law would be revised on the subject of amnesty and pardoning (hypothetically speaking, overcoming the constitutional barriers), according to what was voted in the referendum, in the sense of excluding the corruption offenses, we get to test a hilar situation. In concreto, amnesty and pardoning would be allowed, for example, for criminal offenders convicted for "crimes against the persons", e.g bodily harm (be it grave) or for "crimes against the person and property", e.g. robbery, but not for corruption offenses?! The criminal policy of a country should not be vitiated by the repugnance emotion towards certain individuals and, of course, it should not be a "presidential coin currency in an electoral market". The criminal policy must be based on general principles of law and legal reasoning within the (constitutional) rule of law ratio. Citizens cannot assume the position of specialists in criminal law, and the president, as mentioned above, should not play a role of a popular justice legislator, as there is a risk of affecting the coherence of state policies. The parliamentary and government slippages should be tamed and eliminated in other ways, through constitutional loyalty and political coherence. The empowerment of the president, contrary to the Constitution, as it was thought and engineered in 1991, is not the solution, but a counter move that revives historical mandala of the head of state authoritarianism.

In extension, here is what art. 7 of Law no. 189/1999 regarding the exercise of the legislative initiative by the citizens:

"The Constitutional Court, ex officio or based on the notification of the President of the Parliament's Chamber to which the initiative was registered, will verify:

a) the constitutional character of the legislative proposal that is the object of the initiative..." (our translation from Romanian [12])

Hence, if the citizens' legislative initiative involves the revision of the fundamental law (we therefore exceed Article 74 of the Constitution), the CCR shall take notice ex officio, and start the constitutionality control procedure (regulation formulated in accordance with Article 146 letter a) of the Constitution). Keeping this logic in our legal reasoning equation, with awareness on the differences implied by the object, we may ask: if a referendum may generate an expression of popular will that can

30 sciendo Journal of Legal Studies Volume 24 Issue 38/2019 ISSN 2457-9017; Online ISSN 2392-7054.

Web: publicatii.uvvg.ro/index.php/jls. Pages $23-43$ 
The Romanian prezidentialized consultative referendum. Eating apples from poisonous tree? Personal and teological interpretations

only be objectified through constitutional revision, does the CCR no longer have to verify, ex officio, the object of the referendum, just because it is an advisory popular checkup? The CCR established that the result of a referendum, be it consultative, must be respected, as it evokes the sovereign will of the People [13].

Article 152 of the fundamental law imposes limits on the content of the revision. It would be interesting to look at the position of the Constitutional Court in a case in which the president would, through the consultative referendum, submit a question of general interest likely to receive an answer which, for its political concretization, would need to exceed the revision limits provided by the Constitution. Will the President be allowed to organize an obviously useless consultative referendum, with no public purpose, which consumes - in vain - public money?

But let us to return to art. 74 paragraph 4 of the Constitution. Even if the legislative initiative would be signed, hypothetically speaking, by all citizens with the right to vote, the legislative proposal does not take a parliamentary deliberative form in the situation in which the proposal concerns pardoning or amnesty. Interestingly, citizens can initiate the revision of art. 74 paragraph 4 of the Constitution, which is about limits on amnesty and pardoning.

Anyhow, it was clear that, through the first question of the referendum, a revision of the Constitution was proposed, in the sense of introducing a constitutional provision regarding amnesty and pardoning. Such an outcome would be outside the limits of constitutional revision, affecting rights and liberties [14]. So, rhetorically speaking, why wasn't an a priori constitutionality control performed by CCR?

Question 2 - Do you agree with the prohibition on the adoption of emergency ordinances in the field of crimes, punishments and judicial organization and with the extension of the right to attack the ordinances directly to the Constitutional Court? (our translation from Romanian [15])

The answer "yes" implies, again, the revision of the Constitution!

Once again. Can the President, through a consultative referendum, cause constitutional revision? If the principle of constitutional loyalty (and not only) is considered, the answer is: no!

It is true, art. 150 of the Constitution, regulates a right of constitutional revision initiative in the political account of the president. But, nota bene, having as a starting point a proposal for revision from the Government. The president's initiative is conditioned and devoid of an independent presidential volitional baggage. The President, from his position as a guarantor of constitutional conformation, constitutes a first filter of control over the draft law on the revision of the Constitution. If he expresses consent to the Government's proposal, the revision procedure continues and the Constitutional Court ex officio will perform a constitutionality control (extrinsic and intrinsic). CCR, through Decision no. 
The Romanian prezidentialized consultative referendum. Eating apples from poisonous tree? Personal and teological interpretations

799/2011 [16] on the draft law on the revision of the Constitution of Romania, established, verifying the extrinsic conditions implied by art 150, that the head of state may partially accept the Government's proposal and complete it, because, otherwise, his initiative right would be emptied of content [17]. We do not agree with this interpretation. By embracing the Court's interpretation, it would mean that article 150 is unnecessarily conditioning the President's initiative with the Government's proposal. At the same time, applying the type of reasoning used by the Court, it would mean that the Government's proposal could be emptied of content by the president. Any presidential disagreements in relation with the Government's proposal will have to be overcome by finding a consensus. The President cannot impose his point of view, as it would be equivalent with an action of canceling the Government's proposal - a sine qua non element for initiating the revision procedure [18].

As such, we consider that the consultative referendum cannot lead through its outcome to a constitutional revision. We may ask: is it constitutionally fair (correct) to use the consultative referendum with the aim to impose a morallypolitical pressure against the Parliament or against the Government? Such a move on the political chessboard is outside the box of constitutional coherency. The president's right provided by article 90 must be put into practice in the interest of the People, not for the benefit of a personal political agenda.

Thus, an a priori constitutional control over the object of the consultative referendum is required, considering that, at least theoretically, a referendum is organized with the intention of producing effects in the benefit of the holder of national sovereignty, and the supremacy of the Constitution must be respected. According to art. 146 lit. i), the Constitutional Court monitors the procedure for organizing and conducting the referendum and confirms its results. It can be considered that the fundamental law offers the possibility for the Constitutional Court to sanction the unconstitutionality of a consultative referendum, starting from the object that is put in the decision procedure of the People. The procedure for organizing a referendum also involves the observance of pre-existing constitutional rules, an observance on the limits regarding the constitutional role and attributions of the public authorities involved.

Let's go back to the content of question 2 .

Thesis 1: (...) the prohibition on the adoption of emergency ordinances in the field of crimes, punishments and judicial organization

We consider that the real problem is at and with the political actors, not with the legal institution itself. The legal institution in question can prove useful (maybe even "especially") in the field of criminal law, if it is used in real extraordinary situations, which demand urgent regulation.

32 Sciendo Journal of Legal Studies Volume 24 Issue 38/2019 ISSN 2457-9017; Online ISSN 2392-7054.

Web: publicatii.uvvg.ro/index.php/jls. Pages $23-43$ 
The Romanian prezidentialized consultative referendum. Eating apples from poisonous tree? Personal and teological interpretations

\section{Thesis 2: (...) the right to attack the ordinances directly to the Constitutional Court?}

If we use a constitutional law language, a formula of constitutionality control that implies the possibility to directly attack ordinances to the Constitutional Court can mean so much, going even to the point of restructuring the system of constitutionality review, the role and attributes of the Constitutional Court and so on. This is why we have to be very careful with the question addressed via a referendum, be it only consultative. The intention of the president was not to go that far, indeed, but such a question should be much clearer regarding the subjects that can refer directly to the Constitutional Court, for example. Beyond the circumstances of constitutional loyalty avoidance, such questions are far too technical for the ordinary, unspecialized individuals. If the question is simplified too much, in domains of great complexity, the risk of legitimizing, rejecting or confirming more than it was intended is high. But then, if the question is to technically formulated, the People will vote in void.

We consider that a consultative referendum can be unconstitutional, even if, in isolation, the text of article 90 of the Constitution is respected. When working with law, legal corroborations may be required for finding the ratios of and behind the institutions. When we work in the sphere of constitutional law, this requirement of normative corroboration is deepened.

In order to further substantiate the ideas underlined in section II, we shall "ask" the constitutional founding father from 1991 to share some opinions regarding the consultative referendum.

\section{Some teleological interpretations on the consultative referendum}

We draw attention to the fact that the current section is built on a historical picture having a metaphorical background. We did so in order to better illustrate the already emphasized critical ideas. We will focus on the corroboration of three articles, which we consider can be with the same thread of constitutional logic, even if, at a first glance, they have contrasting objects and ratios.

\section{Article 80 [19] - The role of the President}

(1) The President of Romania shall represent the Romanian State and is the safeguard of the national independence, unity and territorial integrity of the country.

(2) The President of Romania shall guard the observance of the Constitution and the proper functioning of the public authorities. To this effect, he shall act as a mediator between the Powers in the State, as well as between the State and society.

Article 74 [20] - The legislative initiative 
The Romanian prezidentialized consultative referendum. Eating apples from poisonous tree? Personal and teological interpretations

(1) A legislative initiative shall lie, as the case may be, with the Government, Deputies, Senators, or a number of at least 100,000 citizens entitled to vote. (...)

(2) A legislative initiative of the citizens may not touch on matters concerning taxation, international affairs, amnesty or pardon.

\section{Article 90 [21] - Referendum}

(1) The President of Romania may, after consultation with Parliament, ask the people of Romania to express, by referendum, their will on matters of national interest.

Article 80 is about the size of the basket. Article 74 is about apples and article 90 is about pears. At one point, we will mix them.

In article 74, regarding the legislative initiative, it is established how apples are divided and eaten. Citizens do not have access to all the varieties of apples, because they cannot digest them all. Their stomach does not support them. Let's say their "stomach" can't read their structure, so they can't assimilate them. Therefore, they cannot express legislative initiatives regarding fiscal issues, international issues, amnesty and pardon.

In 1991, the Constitution draft did not provide "pardon" as a limit for the legislative initiative of the citizens. It was introduced following the admission of the amendment introduced by Ionel St. Alexandru (senator belonging to National Salvation Front party). The Commission, without formulating a point of view, agreed to the senator's argument, as shown below:

"Pardon is strictly a legal issue and is granted for strictly criminal policy arguments, and cannot be left to the citizens' initiative." (our translation from Romanian [22])

In other words, citizens cannot, for reasons concerning capacity and criminal law technique, enter into such complex decision-making processes, as they do not have and cannot process the arguments that may arise from the fullness of the ratios that builds up the criminal law policy. This was the reason why amnesty was inserted in the constitutional text from the very beginning. It was the place for "pardon" institution too. And it was granted. The stated logic is preserved and extrapolated also in the case of fiscal problems and those of international character. Other issues could have been discussed, but we shall not concentrate on that problematic.

Article 90 of the Constitution is about the consultative referendum. The President, after consulting Parliament, can ask the people to express, by referendum, their will regarding issues of national interest.

In 1991, Mihai Ruva (PNL senator), introduced an amendment with the purpose of limiting the object of the consultative referendum. The amendment was as follows:

"The referendum for fiscal and budgetary, amnesty and empowerment

34 Sciendo Journal of Legal Studies Volume 24 Issue 38/2019 ISSN 2457-9017; Online ISSN 2392-7054.

Web: publicatii.uvvg.ro/index.php/jls. Pages $23-43$ 
The Romanian prezidentialized consultative referendum. Eating apples from poisonous tree? Personal and teological interpretations

measures for ratification of international treaties is not allowed" (our translation from Romanian [23]

The Commission's response, in the sense of rejection, was this:

"The limits to which the amendment refers are characteristic for the situations in which the referendum initiative belongs to the voters and the reason for their establishment - which cannot be sustained if the referendum is initiated by the state organs - lies in the fact that the state's own policy regarding finances and the application of punishments or respectively external relations would be affected." (our translation from Romanian) [24].

Above all, it may be a positive thing that the amendment was rejected, because the admission would have meant the following fact: everything that was not mentioned is allowed.

At a first glance, the conclusion would be clear. We understand and accept the fact that it is risky to mix apples with pears. And it seems that article 74 is about something, and article 90 about something else. The CCR also stated that, in the Decision no. 2 of June 27, 2019 [25]. But in the Decision no. 98/2008 CCR mixed, not very coherent - using pro presidential political interpretative lenses -, article 77 paragraph 2 with article 85 paragraph 2 [26].

If we pay more attention, we can see that it is more important to understand why apples are apples and pears are pears and, more than that, how we differentiate them and why, however, we can eat them together, based on constitutional coherency ratios. Furthermore, we promised that we will mix, at one point, apples with pears.

Let us return to the Commission's reasoning, i.e. to the "reply" given to senator Ruva. Ab initio, it should be noted that the motivation given by the Commission is one of principle, as it does not make determinations among the state authorities that can express state policy positions. In order to identify these authorities and in order to observe the extent to which they can express certain state policy positions, we should take into account the plenitude of the Commission's arguments, namely the motivations for rejecting other amendments, introduced on the same article regarding the referendum or in relation.

Leonard Fințescu (FSN senator) introduced an amendment proposing the elimination of the president's obligation to consult the parliament, because otherwise it would mean that his role and duties are dependent on other authorities will.

The Commission rejected the proposal, arguing that:

"The text of the project follows the collaboration between the President and the Parliament regarding the consultation of the people and tries, at the same time, to prevent a discretionary usage on the part of the president." 
(our translation from Romanian [27])

Furthermore, Țărnea Marta (FSN deputy), with the scope of reformulation art. 89 of the Draft (currently article 90, in force), proposed the following formula:

"In matters of national interest, the people may express their will by referendum, at the proposal of the President or Parliament, with the agreement of the other." (our translation from Romanian [28])

In other words, the initiative for a consultative referendum would have belonged to the president and the parliament. Once the initiative was expressed, it had to be followed by a confirmation from the other authority.

The Commission rejected the amendment, stating:

"The referendum is not decided by mutual agreement. The parliament does not need to resort to the people's consultation, because it is presumed that it acts in the name of the people and it is after all the representative body." (our translation from Romanian [29])

Nota bene, if we rush to conclusions we might think that the consultative referendum, since it is not a constitutional creation useful to the parliament, is a tool that belongs exclusively to the president and, therefore, would be free of volitional barriers. The Commission expressed the contrary, as it was emphasized earlier, on senator Fintescu's amendment. The president does not have a discretionary will when it comes to states policies and, thus, when it comes to consider the objects of the consultative referendum [30].

Several aspects can be denoted from the Commission's motivation:

1) the fact that we have to corroborate the role and attributions of the parliament with the purpose and object of the consultative referendum (naturally, the logic is also highly maintained in the case of the president).

2) the fact that the Parliament has an active role regardless of the political context

3 ) it is the Parliament that primarily represents the People

4) the consultative referendum has no utility / purpose for the Parliament

All these draw, through their thread of logic, other small conclusions. Specifically, through a consultative referendum or through other political-constitutional instruments, the president cannot:

a) play a role outside the limits dictated by the fundamental law,

b) widen his powers, especially when it would affect the superiority of the Parliament, for example.

The Constituent debated and established (by restricting the presidential attributions) what the president cannot do - the leitmotiv of political noninterference. Maybe it would have been better if the Constituent concentrated more on what the president can do than on what he cannot do. By doing so, probably we

36 Sciendo Journal of Legal Studies Volume 24 Issue 38/2019 ISSN 2457-9017; Online ISSN 2392-7054.

Web: publicatii.uvvg.ro/index.php/jls. Pages $23-43$ 
The Romanian prezidentialized consultative referendum. Eating apples from poisonous tree? Personal and teological interpretations

would have come to know more about the consultative referendum, which now seems to be "abandoned" in the freely care of the head of state.

Regarding the content of the role of the president, the FSN parliamentary group proposed the elimination of the formula "good functioning of public authorities" from the definition of the president's role, on the ground that:

"If the President of Romania is to keep a watch over the proper functioning of public authorities, he would have the right to control and instrument these authorities, i.e. the Parliament, the courts, the Superior Council of Magistracy, the Constitutional Court etc. Or, such a right exceeds the constitutional status which, considering this thesis, would not be in accordance with the attributions conferred by the other provisions of the draft Constitution." (our translation from Romanian [31])

The Commission's response, given in the direction of rejecting the amendment, was clear and correct:

"The text of the project was approved through vote by the Constituent Assembly, as a structural element of the presidential function. It does not imply, in anyway, an intrusion in the activity of public authorities." (our translation from Romanian [32])

Therefore, the presidential function has a certain structure that involves clear barriers, i.e. involvement in the activity of other public authorities. This is how and why the consultative referendum has limits in the expression of its object.

The Commission said that the state authorities are the ones setting the state policy. Obviously, some state authorities have a special dynamic in this policy. The president, by his role and by his relativized and conditioned attributions, does not have such a determining or dynamic role, especially in the conditions in which he cannot intervene in the activity of other public authorities.

The Commission particularizes - indirectly - the public authorities in relation with the subject of a referendum, when it underlines the futility of a referendum initiated by the Parliament. Hence, if the president cannot get his political agenda inserted in the legislative activity (for example), how could he submit to a referendum something that would distort the state policy entrusted to the Parliament? How could the president express state policies on finances, on the application of penalties or regarding international relations, for example? As such, how can the People express, at the initiative of a state organ that does not have the necessary leverages to objectify the popular response, a position of state policy that does not fit in the Parliament's state policy regarding, e.g. amnesty or pardon? How can such a situation be generated? With the help of a president that chooses to interfere, through the consultative referendum, in the activity of other public authorities, even though, as the constitutional Founding Fathers stated, he may not intervene, in 
In consequence, even if it sounds paradoxical, we have to mix apples with pears (coherently, of course). If we mix them incoherently, the president gives the pears that he does not have to the citizen's, for consumption, and the later return the apples (although received as pears) that they cannot eat (process). Surprisingly, neither the president can consume those apples, even though he may claim they are pears; and the Parliament may not need or desire on the apples or pears (it holds the basket in any form of content, i.e. state policies). The president has other counterleverages ever the consumption of unconstitutional apples / pears in the Parliament. Let us not forget that, in the initial constitutional theses, there was a variant of a legislative referendum, within the presidential attributions (Title III, Chapter 2, thesis 6, point 6: At the proposal of the government, if the parliament is in session, and at the proposal of the two chambers, he [34] may submit to a referendum any draft law concerning issues of state policy; promulgation of laws adopted by referendum is mandatory within the same 15-day period.). It should be noted that it was removed due to the establishment of the authority that the president would have gained. It was considered that such a possibility left in the presidential hands (as in the case of the French president), would have brought great risks in the direction of political power personalization. The pulse of the debates was clear in the sense of eliminating the direct or semi-direct legislative possibilities of the president, especially under the conditions in which it was assumed that he will be (officially or not), most likely, a (ex) political party president. Great risks, rich past authoritarian experiences. Most interventions during the Constituent Assembly debates have been addressed to the presidential institution. They were focused on avoiding the involvement of the head of state in effective governance constitutionalism based on anxiety, aversion, repugnance toward the head of state historic authority.

\section{Conclusions}

In order to be better or correctly understood. We consider that a consultative referendum is necessary and useful in a society that aims to be connected to democratic values based on objective deliberative channels. The president, based on his electoral legitimacy and taking into account the attributions that outline his constitutional role, should have the political possibility to make use of the aims of a consultative referendum, but, as we have already stated, these aims should not be outside the box of popular interests and, most importantly, capacities. Moreover, the aims should not be electoral-presidential, programed for discrediting the Parliament or other public authorities. By doing so, the president is abandoning his constitutional mission, set by article 80 of the fundamental law. 
The Romanian prezidentialized consultative referendum. Eating apples from poisonous tree? Personal and teological interpretations

The absolutisation of the referendum's object in the will of the president does not have constitutional foundations. However, in the political-constitutional praxis, the interpretations reached a point where article 90 is perceived as an absolute right of the president (CCR has made a strong contribution in this sense [35]). It must be understood that the consultative referendum is not a power leverage in the president's account, but a mediated political power expression of the People. It is about the interests of the people [36] and not about the president's personal political agenda or of another. The leverage "consultative referendum" should be (re) connected (up to the level of full dependency), in its use and purpose, to the principle of constitutional loyalty between authorities, and the teleological interpretation should be carried in the form of a longer logical thread, not only segmented, all the more so as to understand and tame the dynamic and contextually changeable avatars of the semi-presidential regime. The president of Romania exercises a high responsibility in front of the People, because he is a counter-model of the communist president. A paradox, yet, emerges. The People request, from time to time, a strong state leader, a savior of the nation. This is how authoritarianism is further unlocked through unconscious popular legitimization. You cannot completely outrun the past, we may say.

The consultative referendum could include the symbolism of a political veto given, in certain situations, to the parliament, in representing the interests of the nation. However, no one requested and attributed this mission to the head of state, through the discussed instrument, but on the contrary, the debates of the Founding Fathers of the Constitution reveal the cancellation of such a possibility. However, the living constitution is inevitably in a continuous dynamic, determined by mentalities and capacities (active and passive), while the constitutional form is static and, due to the living constitution, becomes alien to teleological interpretations. Thus, the form must be connected to the societal background and vice versa. It is not surprising, therefore, that the living political system of Romania translates inclinations toward presidentialisation, despite having marked a different political road in the constitutional form (the written fundamental law).

\section{Acknowledgements}

The author thanks the anonymous reviewers and editor for their valuable contribution.

\section{Funding}

This research received no specific grant from any funding agency in the public, commercial, or not - for - profit sectors. 
The Romanian prezidentialized consultative referendum. Eating apples from poisonous tree? Personal and teological interpretations

\section{Author Contributions}

The entire article was written by Răzvan Cosmin Roghină.

\section{Disclosure Statement}

The authors have not any competing financial, professional, or personal interests from other parties.

\section{References}

1. CCR Decision no. 70/1999;

2. CCR Decision no. 567/2006;

3. CCR Decision no. 147/2007;

4. CCR Decision no. 355/2007;

5. CCR Decision no. 33/2009;

6. CCR Decision no. 799/2011;

7. CCR Decision no. 682/2012;

8. CCR Decision no. $731 / 2012$

9. CCR Decision no. 334/2013;

10. CCR Decision no.80/ 2014;

11. CCR Decision/Ruling no. 2/ 2019;

12. Geneza Constituției României 1991. Lucrările Adunării Constituante, Regia Autonomă "Monitorul Oficial", 1991;

13. https://www.presidency.ro/en/the-constitution-of-romania

14. Law no. 189/1999 - on the exercise of the legislative initiative by citizens (in Romania) 15. Roghină R.C., The Constitutional Court of Romania against the Direction of the Constitutional Moment of 1991, Journal of Legal Studies, Vol 20, Issue 34 (2017)), pp. 3851.

16. Roghină R.C., The survival of the Romanian Head of State Authoritarianism in Romanian Democracy through the Consultative Referendum, Romanian Journal of Comparative Law, Vol. 9, Issue 1 (2018), pp. 119-152

17. The Constitution of Romania (1991, revised in 2003)

\section{Notes}

[1] Romanian Journal of Comparative Law, Vol. 9, Issue 1 (2018), pp. 119-152

[2] Journal of Legal Studies, Vol 20, Issue 34 (2017)), pp. 38-51.

[3] This section represents a developed version of the section "The praxis of article 90 of the constitution" from the article The survival of the Romanian Head of State Authoritarianism in Romanian Democracy through the Consultative Referendum ...cit., pp. $145-147$.

[4] See the bibliographical reference of note [1].

[5] See article 80 of the Romanian fundamental law (the Constitution emphasizes a mediator role)

40 S sciendo Journal of Legal Studies Volume 24 Issue 38/2019

ISSN 2457-9017; Online ISSN 2392-7054.

Web: publicatii.uvvg.ro/index.php/jls. Pages $23-43$ 
The Romanian prezidentialized consultative referendum. Eating apples from poisonous tree? Personal and teological interpretations

[6] E.g., Decision no. 70 of 1999; Decision no. 567/2006; Decision no. 147/2007; Decision no. 355/2007; Decision no. 334/2013.

[7] https://www.ccr.ro/files/products/D0334_133.pdf

[8] https://www.ccr.ro/files/products/D0334_133.pdf, pp. 13-14.

[9] Question 1: Sunteți de acord cu interzicerea amnistiei și grațierii pentru infracțiuni de corupție?

[10] https://www.ccr.ro/files/products/D070_99.pdf
[11]
In Decision
no.
2
of June
27 ,
2019

(http://www.ccr.ro/download/decizii_relevante/HOT-nr2.pdf, p. 11), regarding the constitutional control on the procedure for organizing and conducting the national referendum of May 26, 2019 and regarding the confirmation of its results, the Court found that the provisions of Article 74 paragraph (2) of the Constitution regulate the limits of the citizens' legislative initiative, and not of the consultative referendum, stating that two distinct constitutional institutions are discussed, with different legal regime. Indeed, two different constitutional institutions are in question, but which, we consider, reveal a common logical thread, which can be used for finding a constitutional coherence between certain articles of the fundamental law. See, infra, section III of the paper. In Decision no. $98 / 2008$, on the request for a resolution concerning a legal conflict of constitutional nature between the President of Romania and the Government of Romania, CCR understood that it is appropriate and logically-constitutional to combine fundamental regulations that refer deeply to different legal objects and relations, forcing a logical thread through inappropriate entanglements. The Court created the president's opportunity to refuse once, but motivated, the person nominated by the prime minister for a ministerial position, stating that: "Regarding the number of cases in which the President of Romania may ask the Prime Minister to make another nomination for the vacant ministerial position, the Court finds that, in order to prevent the emergence of an institutional blockade in the legislative process, the constituent legislator provided in art. 77 paragraph (2) of the Fundamental Law the right of the President to ask the Parliament to re-examine a law before promulgation, only once. The Court considers that this solution has constitutional value as a principle when resolving legal conflicts between two or more public authorities that have joint powers in adopting a measure provided by the Fundamental Law and that this principle is of general application in similar cases. Applied to the process of government reshuffling and appointing ministers in case of vacancies, this solution is likely to eliminate the deadlock that would be generated by the President's repeated refusal to appoint a minister at the proposal of the prime minister." (our translation from Romanian: In ceea ce privește numărul de cazuri în care Președintele României poate cere primului-ministru să facă altă nominalizare pentru funcția de ministru vacantă, Curtea constată că, pentru prê̂ntâmpinarea apariției unui blocaj instituțional în procesul de legiferare, legiuitorul constituant a prevăzut la art. 77 alin. (2) din Legea fundamentală dreptul Președintelui de a cere Parlamentului reexaminarea unei legi înainte de promulgare, o singură dată. Curtea apreciază că această soluție are valoare constituțională de principiu în soluționarea conflictelor juridice între două sau mai multe autorități publice care au atribuții conjuncte în adoptarea unei măsuri prevăzute de Legea fundamentală și că acest principiu este de 
Roghină, R.C., (2019)

The Romanian prezidentialized consultative referendum. Eating apples from poisonous tree? Personal and teological interpretations

aplicațiune generală în cazuri similare. Aplicată la procesul de remaniere guvernamentală și de numire a unor miniștri în caz de vacanță a posturilor, această soluție este de natură să elimine blocajul ce s-ar genera prin eventualul refuz repetat al Președintelui de a numi un ministru la propunerea primului-ministru”). Without developing a critique on the Court's rationale, we shall resume on emphasizing the fact that completely different institutions and constitutional processes were absurdly combined. At the same time, we observe different attitudes depending on the public authority involved.

[12] Article 7 of Law no. 189/1999: „Curtea Constituțională, din oficiu sau pe baza sesizării președintelui Camerei Parlamentului la care s-a înregistrat inițiativa, va verifica: a) caracterul constituțional al propunerii legislative ce face obiectul inițiativei; (...)"

[13] Decision no. 682 of June 27, 2012; Decision no.80 of February 16, 2014. In Decision no. 2 of June 27, 2019 (http://www.ccr.ro/download/decizii_relevante/HOT-nr2.pdf, p. 9), The Court develops a more reserved position on the effects of a consultative referendum, highlighting the primordiality of the political effects. At the same time, the Court admits that "such a referendum may also include the adoption of legislative acts, insofar as this is the way in which the authorities decide to implement the result of the popular consultation or it may cause a refusal to regulate, contrary to the will expressed by the voters" (our translation from Romanian: un astfel de referendum poate determina inclusiv adoptarea unor acte cu caracter legislativ, în măsura în care aceasta este modalitatea prin care autoritățile decid să pună în operă rezultatul consultării populare sau poate determina o conduită de abținere de a reglementa în sens contrar voinței exprimate de votanți). We believe that this statement should have been filtered, first of all, through the principle of constitutional loyalty between authorities. In the case of the consultative referendum of May 26, 2019, the questions were not formulated with constitutional loyalty ratio and the citizens understood that they were called to give their agreement on some intentions of legislative / constitutional revisions necessary for saving democracy and rule of law.

[14] http://www.ccr.ro/download/decizii_relevante/HOT-nr2.pdf

[15] Question 2: Sunteți de acord cu interzicerea adoptării de către Guvern a ordonanțelor de urgență $\hat{\imath}$ domeniul infracțiunilor, pedepselor și al organizării judiciare și cu extinderea dreptului de a ataca ordonanțele direct la Curtea Constituțională?

[16] https://www.ccr.ro/files/products/D0799_11.pdf

[17] Ibid, p. 10.

[18] R.C. Roghină, The survival of the Romanian Head of State Authoritarianism in Romanian Democracy ...cit., p. 132.

[19] The Romanian Constituion - english version availbale on https://www.presidency.ro/en/the-constitution-of-romania (the oficial site of the Presidential Adminsitration), web pgae accesed on 01.10.2019.

${ }^{[20]}$ Ibidem

[21] Ibidem

[22] "Grațierea este o problemă strict juridică și se acordă pentru argumente de politică strict penală, neputând fi lăsată la inițiativa cetățenilor." (Geneza Constituției României 1991. Lucrările Adunării Constituante, Regia Autonomă "Monitorul Oficial”, p. 627).

42 sciendo Journal of Legal Studies Volume 24 Issue 38/2019 ISSN 2457-9017; Online ISSN 2392-7054.

Web: publicatii.uvvg.ro/index.php/jls. Pages $23-43$ 
The Romanian prezidentialized consultative referendum. Eating apples from poisonous tree? Personal and teological interpretations

[23] „Nu se admite recurgerea la referendum pentru măsuri fiscale și de buget, de amnistie şi de împuternicire pentru ratificarea tratatelor internaţionale" (ibidem, p. 639).

[24] „Limitele la care se referă amendamentul sunt caracteristice situațiilor în care inițiativa referendumului aparține alegătorilor și rațiunea instituirii lor - care nu poate subzista în cazul în care referendumul este pornit din inițiativa organelor statului - rezidă în faptul că sar afecta însăși politica statului cu privire la finanțe și respectiv aplicarea pedepselor ori relațiile externe." (ibidem)

[25] http://www.ccr.ro/download/decizii_relevante/HOT-nr2.pdf, p. 11

[26] See supra note [11].

[27] Textul din proiect urmărește colaborarea dintre Președinte și Parlament în ceea ce privește consultarea poporului și încearcă, în același timp, îngrădirea utilizării lui discreționare de către președinte (Geneza ... cit., p. 639).

[28] 'În probleme de interes național, poporul poate să-și exprime voința prin referendum, la propunerea Președintelui sau a Parlamentului, cu acordul celeilalte părți.” (ibidem)

[29] "Referendumul nu se hotărăște de comun acord. Parlamentul nu are nevoie să recurgă la consultarea poporului pentru că se prezumă că el acționează în numele poporului care 1-a ales și este însuși organul reprezentativ". (ibidem)

[30] It is true, the CCR jurisprudence may translate an absolute presidential right, which is wrong, we consider

[31] 'Dacă președintele României ar urma să vegheze la buna funcționare a autorităților publice, ar însemna să aibă dreptul de a controla și instrumenta aceste autorități, adică Parlamentul, instanțele judecătorești, Consiliul Superior al Magistraturii, Curtea Constituțională etc.. Or, un asemenea drept excede statutul constituțional care, sub acest aspect, nu este în acord cu atribuțiile conferite prin celelalte prevederi ale Proiectului de Constitui" (Geneza... cit., p. 631).

[32] Textul din proiect a fost însușit prin vot de către Adunarea Constituantă, ca un element structural al funcției prezidențiale. El nu presupune în nici un fel amestecul în activitatea autorităților publice.” (ibidem)

[33] A complementary note: a consultative referendum can be a hindrance against certain political "skids" (including parliamentary), but not with any object thrown into the People's sea of (in)capacities and emotions. The later, whether they are constructive, in essence, should not be converted into electoral capital by distorting the purpose of certain constitutional instruments.

[34] The President.

[35] Supra note [6].

[36] Not all the popular interests are useful to the state and, ironically, to the People; a state should be ruled based on blind or provoked ad summa popular wills (plebiscite) 